US Army Corps

of Engineers ${ }_{\circledast}$

Engineer Research and

Development Center

Integrated Climate Assessment for Army Enterprise Planning

\title{
Range Days Lost to Fire Risk Model User's Guide
}

Byron M. Garton

July 2019

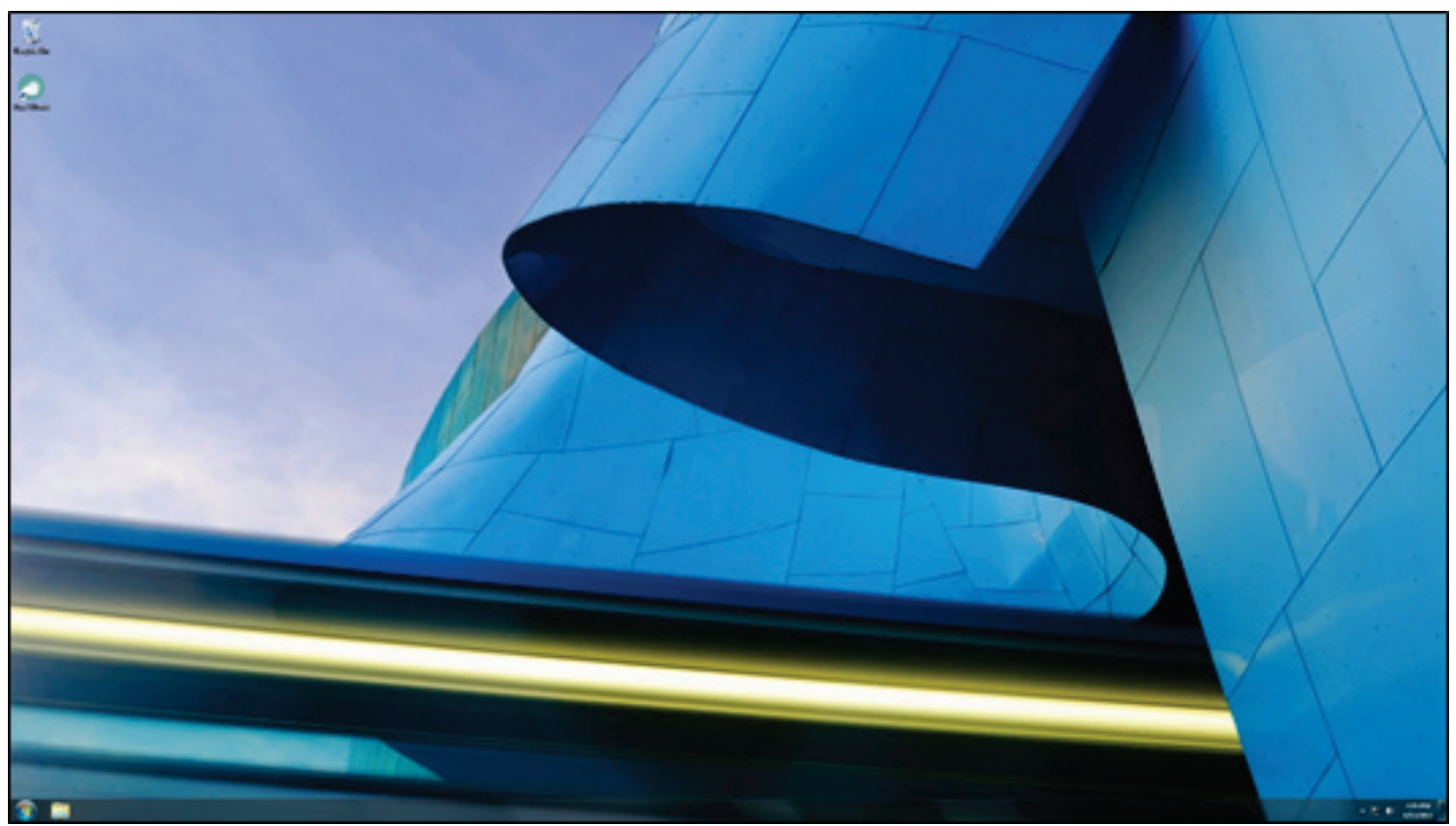


The U.S. Army Engineer Research and Development Center (ERDC) solves the nation's toughest engineering and environmental challenges. ERDC develops innovative solutions in civil and military engineering, geospatial sciences, water resources, and environmental sciences for the Army, the Department of Defense, civilian agencies, and our nation's public good. Find out more at www.erdc.usace.army.mil.

To search for other technical reports published by ERDC, visit the ERDC online library at http://acwc.sdp.sirsi.net/client/default. 


\title{
Range Days Lost to Fire Risk Model User's Guide
}

\author{
Byron M. Garton \\ Information Technology Laboratory \\ U.S. Army Engineer Research and Development Center \\ 3909 Halls Ferry Road \\ Vicksburg, MS 39180-6199
}

Final report

Approved for public release; distribution is unlimited.

Prepared for Headquarters, U.S. Army Corps of Engineers

Washington, DC 20314-1000

Under Project 402188 Integrated Climate Assessment for Army Enterprise Planning 


\section{Abstract}

Maintaining and increasing the capacity to perform live fire training exercises on Department of Defense (DoD) lands is essential to future force readiness and effectiveness. The risk of fire on ranges as a potential result of climate change is one factor affecting the availability of training areas. Assessing the impact of future climate change is an essential part of ensuring future availability of live fire ranges.

This document describes the process of executing the Range Days Lost to Fire Risk Model, as it exists at the time of this writing, within the common computational environment established under the software integration effort of the Integrated Climate Assessment for Army Enterprise Planning work package.

DISCLAIMER: The contents of this report are not to be used for advertising, publication, or promotional purposes. Citation of trade names does not constitute an official endorsement or approval of the use of such commercial products. All product names and trademarks cited are the property of their respective owners. The findings of this report are not to be construed as an official Department of the Army position unless so designated by other authorized documents. 


\section{Contents}

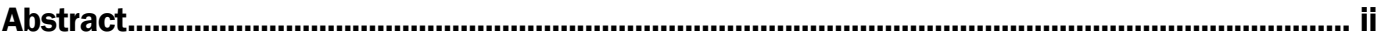

Figures and Tables..................................................................................................................

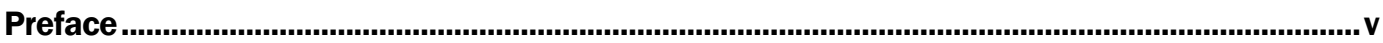

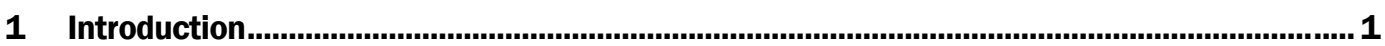

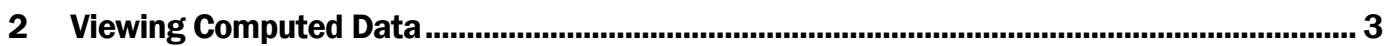

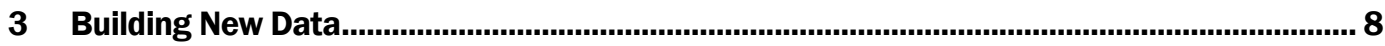

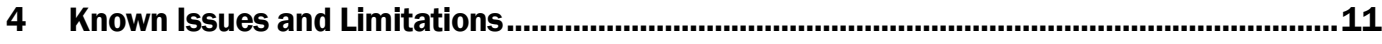

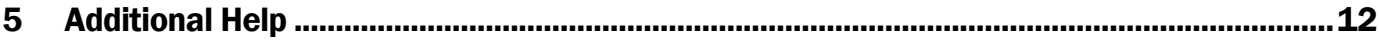

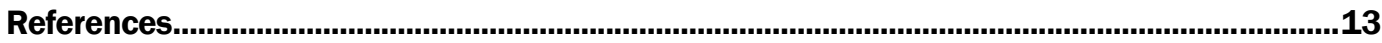

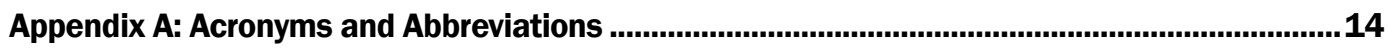

Report Documentation Page 


\section{Figures and Tables}

\section{Figures}

Figure 1. Wizard application shortcut. ...................................................................................... 3

Figure 2. Range Days Lost to Fire Risk Model icon.................................................................... 4

Figure 3. Range Days Lost to Fire Risk Model first screen.................................................................. 4

Figure 4. Range Days Lost to Fire Risk Model second screen......................................................... 5

Figure 5. Results in the chart viewer window. ............................................................................ 6

Figure 6. Launch Python IDLE from the third model screen within the Wizard................................... 8

Figure 7. Python IDLE development environment. ...................................................................... 9

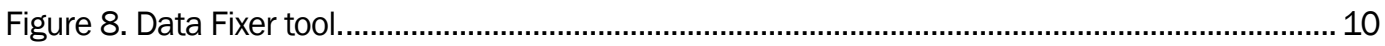

\section{Table}

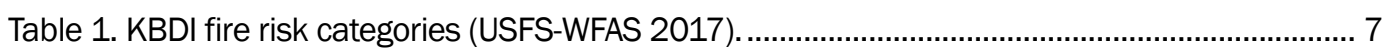




\section{Preface}

This research was conducted for the U.S. Engineer Research and Development Center-Construction Engineering Research Laboratory (ERDC-CERL) under Project 402188, Integrated Climate Assessment for Army Enterprise Planning. The Technical Monitor was Dr. James D. Westervelt of ERDC-CERL.

The work was performed by the Information Technology Laboratory (ITL), Scientific Software Branch (SSB), of the Computational Science and Engineering Division (CSED). At the time of publication, Mr. Timothy W. Dunaway was Chief of the SSB, Dr. Jerrell R. Ballard was Chief of the CSED, and Dr. Robert M. Wallace was the Technical Director. The Deputy Director of ERDC-ITL was Ms. Patti S. Duett, and the Director was Dr. David A. Horner.

COL Ivan P. Beckman was the Commander of ERDC, and Dr. David W. Pittman was the Director. 


\section{Introduction}

\subsection{Background}

The Range Days Lost to Fire Risk Model attempts to predict the likelihood of fires on ranges by calculating a Keetch-Byram drought index (KBDI) for each installation included in the study (USFS-WFAS 2017). The KBDI was devised based on mathematical models for predicting the likelihood of wildfires based on soil moisture and other conditions related to drought. The KBDI is a soil/duff drought index that ranges from o (no drought) to 800 (extreme drought) and is based on the soil capacity in 8 inches (200 mm) of water (USFS-WFAS 2017). The depth of soil required to hold 8 inches of moisture varies. A prolonged drought (high KBDI) influences fire intensity largely because fuels have a lower moisture content (USFSWFAS 2017).

\subsection{Purpose}

High risk of fire on ranges effects the availability of training areas. Maintaining and increasing the capacity to perform live fire training exercises on Department of Defense (DoD) lands is essential to future force readiness and effectiveness. Assessing the impact of future climate change is an essential part of ensuring future availability of live fire ranges. The predicted effect of climate change on range fire risk is intended to be utilized in other force stationing analysis applications as a Military Value Analysis (MVA) attribute.

This model makes use of a common computational environment and a user assistance application that were implemented as part of the Software Integration effort within the Integrated Climate Assessment for Army Enterprise Planning work package. The virtual environment will be referred to throughout this document as the Virtual Machine or VM, and the user assistance application will be referred to as the Wizard. For more information about the Software Integration effort, the virtual environment, and the user assistance application, refer to the Analytical Model Integration Methods technical report listed in the reference section.

Executing the model is a two-step process that requires using Python IDLE development environment, MS Excel ${ }^{\circledR}$, and a basic text editor such as MS 
Notepad ${ }^{\circledR}$. Each step for viewing and building data sets is thoroughly documented in the following sections to limit user confusion and ensure accurate results.

\subsection{Requirements}

Software requirements for the Range Days Lost to Fire Risk Model include the Python IDLE development environment, a basic text editor such as MS Notepad ${ }^{\circledR}$, and MS Excel ${ }^{\circledR}$ version 2013 or higher.

A working knowledge of Microsoft Office products is recommended as well as a basic understanding of editing file paths in a text file and executing Python code within the IDLE environment. 


\section{Viewing Computed Data}

Pre-built dataset viewing is available to end users by accessing the model from within the Wizard application. The Wizard is accessible from the Integrated Climate Assessment for Army Enterprise Planning VM by clicking the shortcut located on the desktop (Figures 1-3).

Figure 1. Wizard application shortcut.

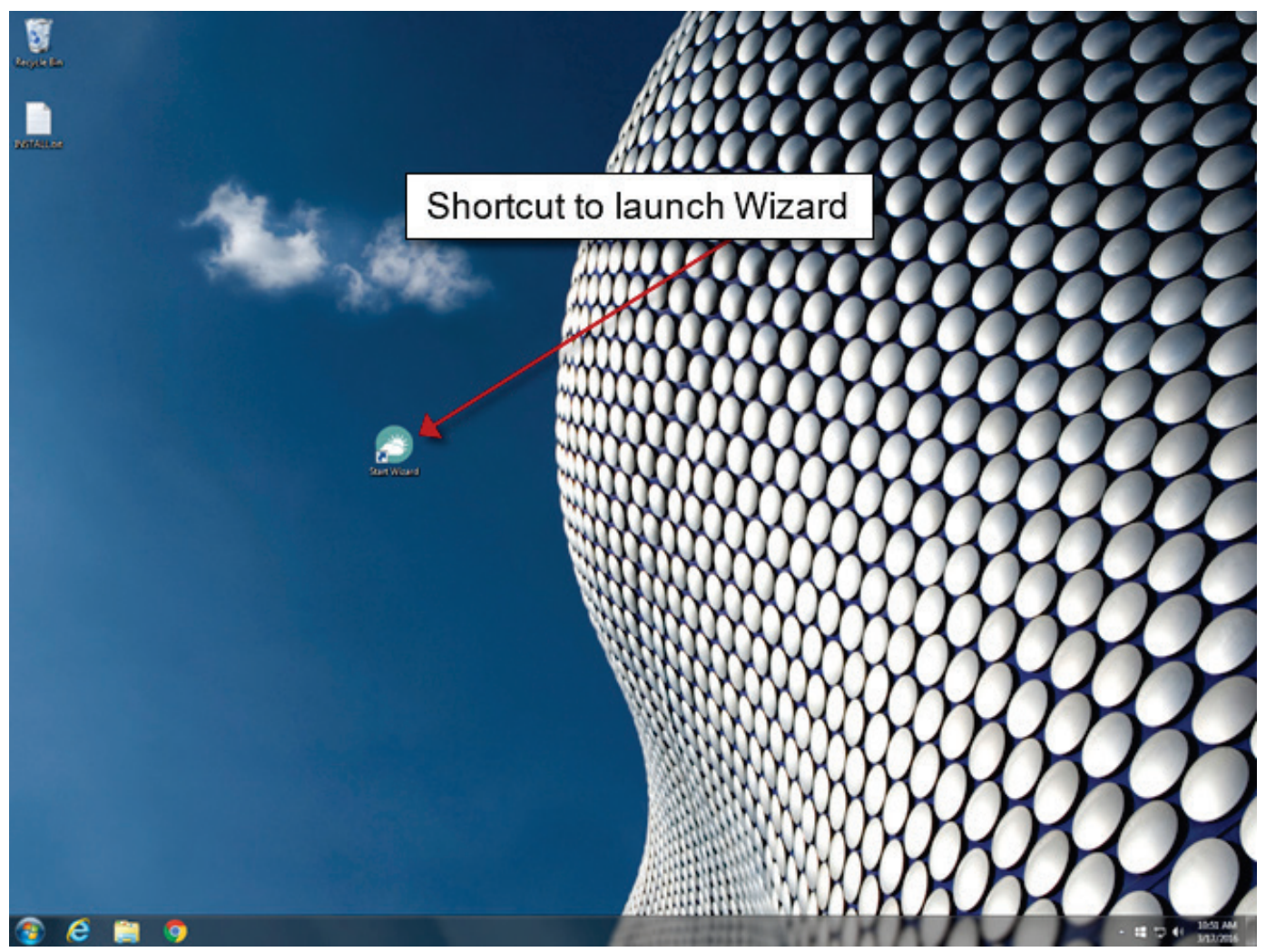


Figure 2. Range Days Lost to Fire Risk Model icon.

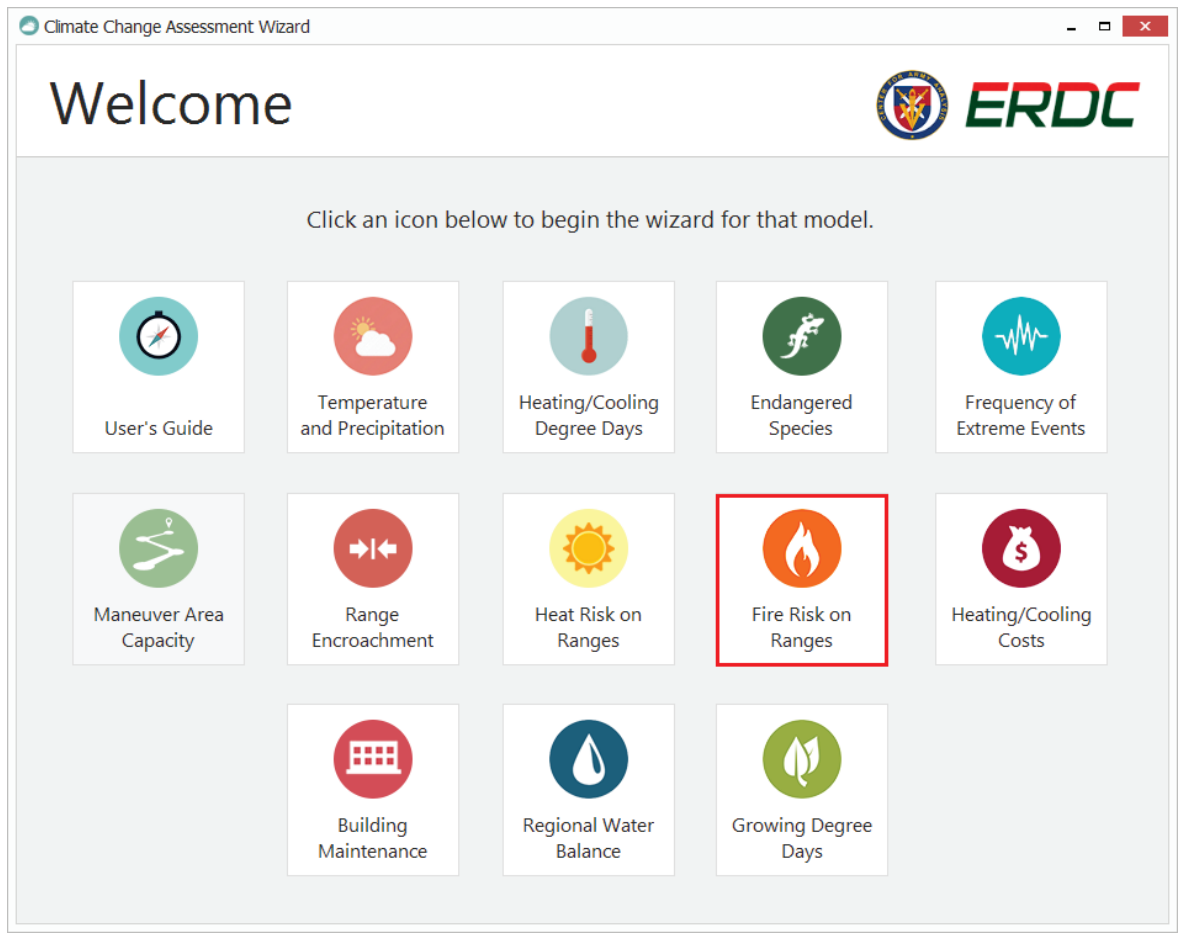

Figure 3. Range Days Lost to Fire Risk Model first screen.

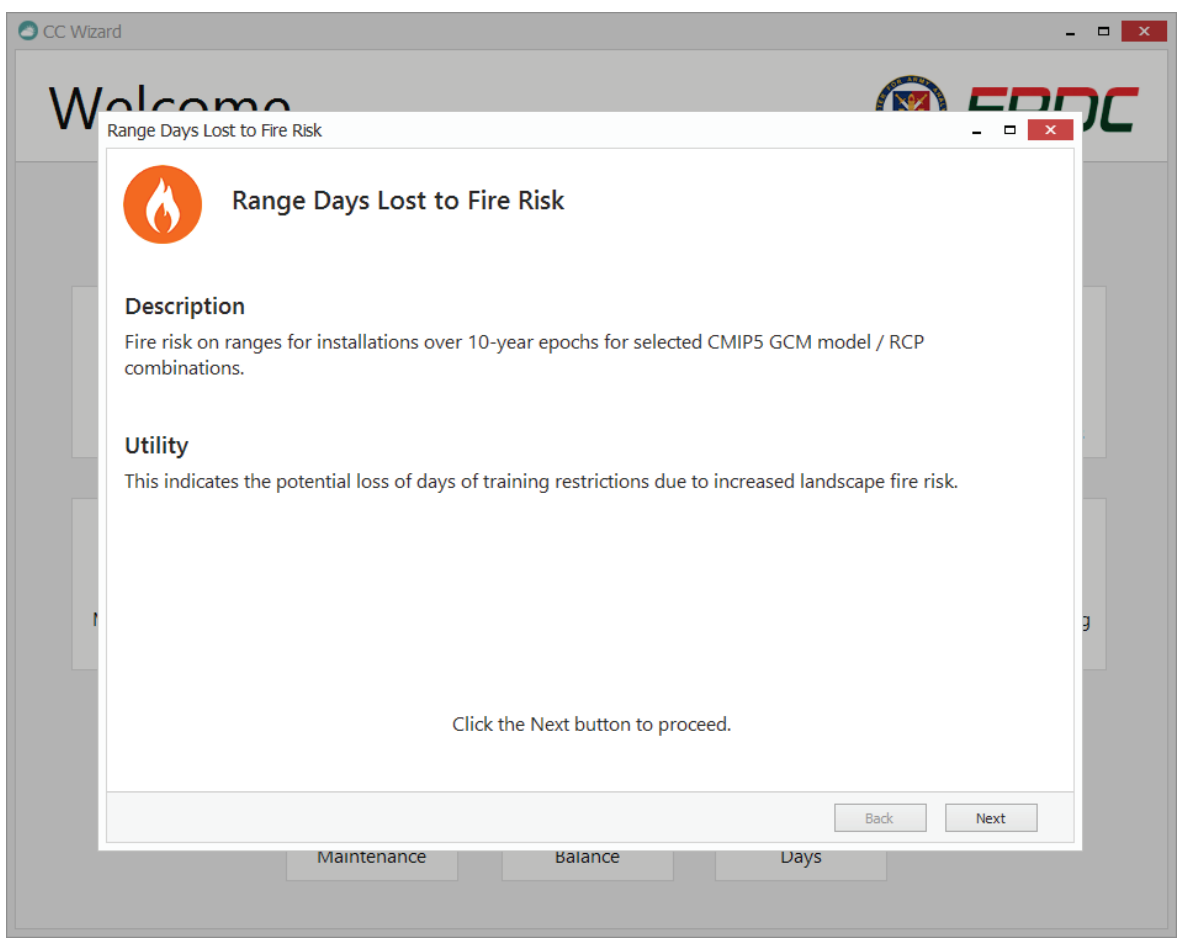

The second screen within the model (Figure 4) allows the end user to view the datasets in graphical or tabular mode. Users can choose the desired view type from the View drop down combo box. Options within this box 
are Graphs and Tabular. Graphs displays the data as standard line graphs while Tabular displays the data in a table layout within an MS Excel ${ }^{\circledR}$ spreadsheet.

Figure 4. Range Days Lost to Fire Risk Model second screen.

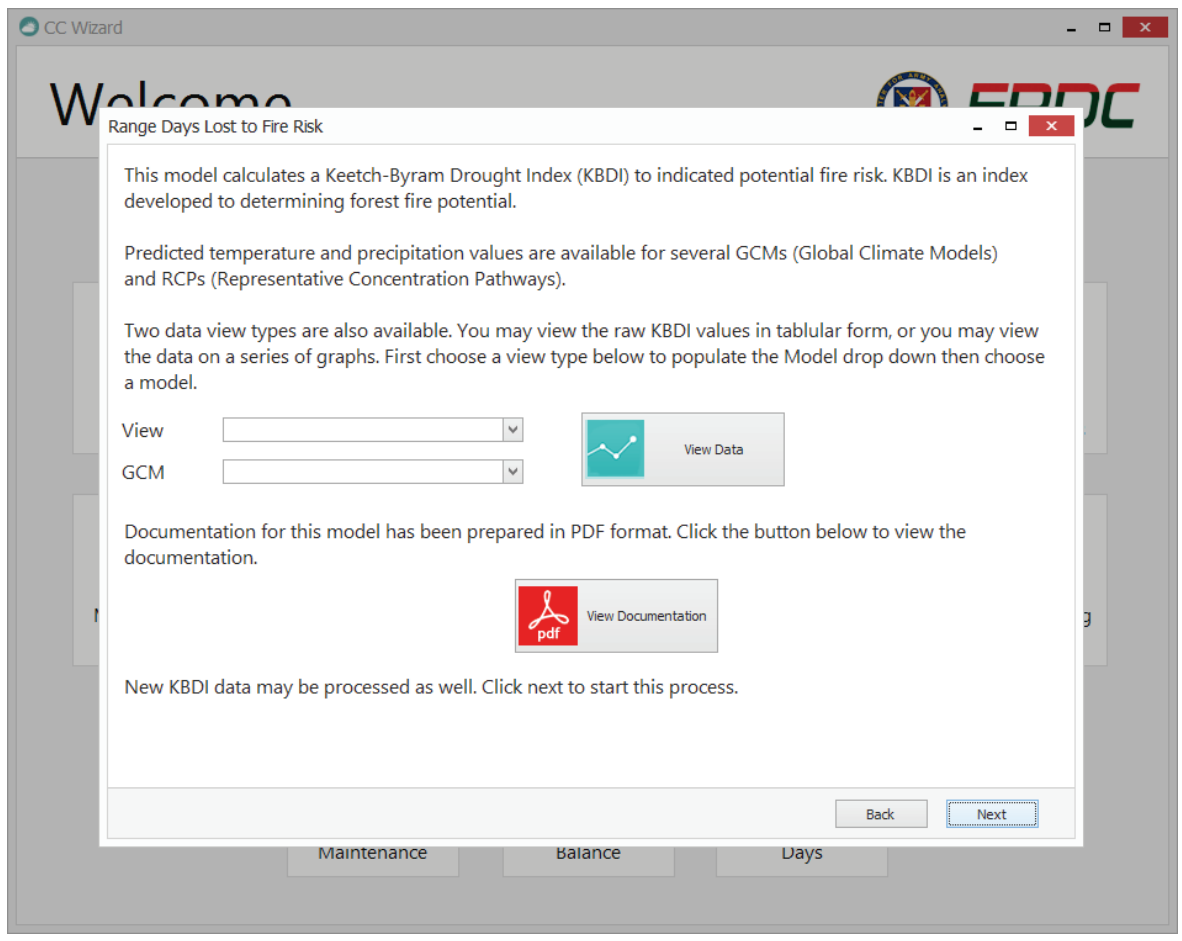

Next, choose a General Circulation Model (GCM) and Representative Concentration Pathway (RCP) type from the drop down combo box to filter only data related to that GCM/RCP. At the time of this publication, there are ten GCMs within the dataset for this model. RCP 2.6, 4.5, and 8.5 were chosen to represent lower bound, middle, and upper bounds for each GCM. Each GCM contains these RCPs, with the exception of CNRM-CM-5 and GFDL-CM3.

Once both of the choices are made, click the View Data button to launch the chart viewer window (Figure 5). 
Figure 5. Results in the chart viewer window.

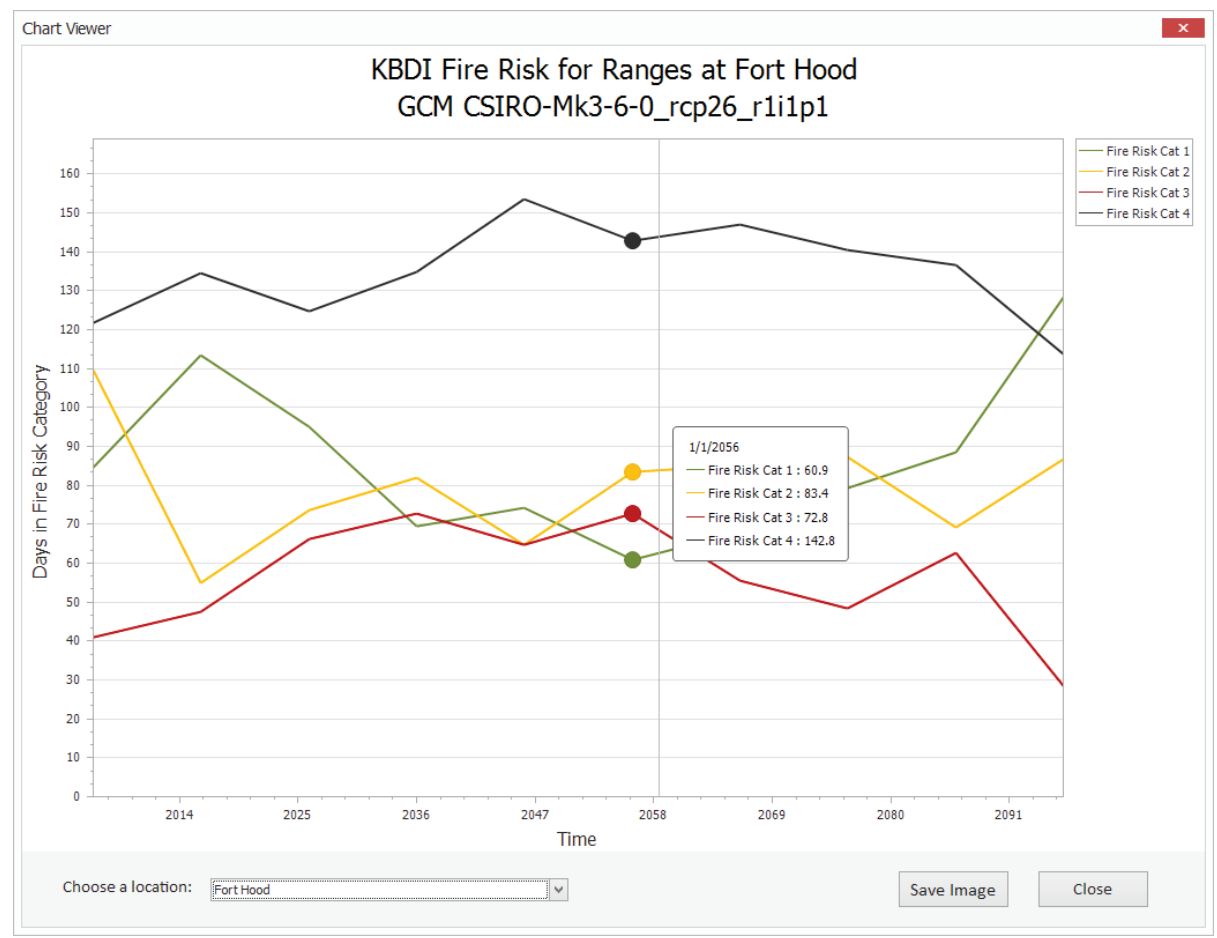

The average number of days in four different fire risk categories are plotted as line graphs with the number of days charted on the $\mathrm{Y}$-axis, and 10-year epochs are charted on the $\mathrm{X}$-axis. The user can change the charted values by choosing a different geographical location from the drop down combo box near the bottom left of the window (Figure 5). Upon selecting a location, the data will automatically filter to include only those values found within the chosen area. Table 1 lists and describes each of the four fire risk (KBDI) categories. 
Table 1. KBDI fire risk categories (USFS-WFAS 2017).

\begin{tabular}{|c|c|c|c|c|c|}
\hline Categrory & $\begin{array}{l}\text { Fre Danger } \\
\text { Condlition }\end{array}$ & $\begin{array}{l}\text { Expected Fre } \\
\text { Behevilor }\end{array}$ & $\begin{array}{l}\text { Training } \\
\text { Restrictions }\end{array}$ & $\begin{array}{l}\text { Fireflinting } \\
\text { Detall } \\
\text { Requirements }\end{array}$ & $\begin{array}{l}\text { Dertwed } \\
\text { KBD|* }\end{array}$ \\
\hline 1 & GREEN & $\begin{array}{l}\text { Fires are difficult to start } \\
\text { and do not burn with } \\
\text { vigor. Fires can easily be } \\
\text { controlled using direct } \\
\text { attack. }\end{array}$ & None. & None. & 0.300 \\
\hline 2 & AMBER & $\begin{array}{l}\text { Fires start easily and may } \\
\text { burn quickly through } \\
\text { grass and shrub fuels. } \\
\text { Fires can be controlled } \\
\text { using direct attack, but in } \\
\text { some circumstances may } \\
\text { require indirect attack } \\
\text { methods. }\end{array}$ & $\begin{array}{l}\text { No aerial flares } \\
\text { outside the live-fire } \\
\text { training areas. } \\
\text { Pyrotechnics must be } \\
\text { used on roadways, } \\
\text { tank trails, or barren } \\
\text { areas. }\end{array}$ & None. & $300-600$ \\
\hline 3 & RED & $\begin{array}{l}\text { Fires start easily, move } \\
\text { quickly, burn intensely. } \\
\text { and may be difficult to } \\
\text { control. }\end{array}$ & $\begin{array}{l}\text { No pyrotechnics, } \\
\text { incendiary munitions, } \\
\text { tracers. }\end{array}$ & $\begin{array}{l}10 \text {-person fire- } \\
\text { fighting detail } \\
\text { required. } \\
\text { on-call helicopter } \\
\text { required on } 20 \text { - } \\
\text { minute standby. }\end{array}$ & $600-750$ \\
\hline 4 & BLACK & $\begin{array}{l}\text { Fires start very easily and } \\
\text { are impossible to control. }\end{array}$ & $\begin{array}{l}\text { No live-fire training. } \\
\text { No pyrotechnics. } \\
\text { Non-live-fire training } \\
\text { must be authorized } \\
\text { by the Senior Mission } \\
\text { Commander. }\end{array}$ & None. & $750-800$ \\
\hline
\end{tabular}

Charts can be saved to the user's computer by clicking the Save Image button near the bottom right of the window (Figure 5). The resulting file is saved to a location of the user's choosing in the universal Joint Photographic Experts Group (JPEG) image file format. 


\section{Building New Data}

Building new datasets is not possible within the Wizard interface but can be accomplished within the VM by running a Python Script from the Python IDLE development environment. The following instructions should be followed carefully to produce new data from this model.

The Python IDLE development environment is pre-installed inside the VM, and may be launched automatically from the Wizard application or accessed from the Windows Start menu (Figure 6 and Figure 7).

Figure 6. Launch Python IDLE from the third model screen within the Wizard.

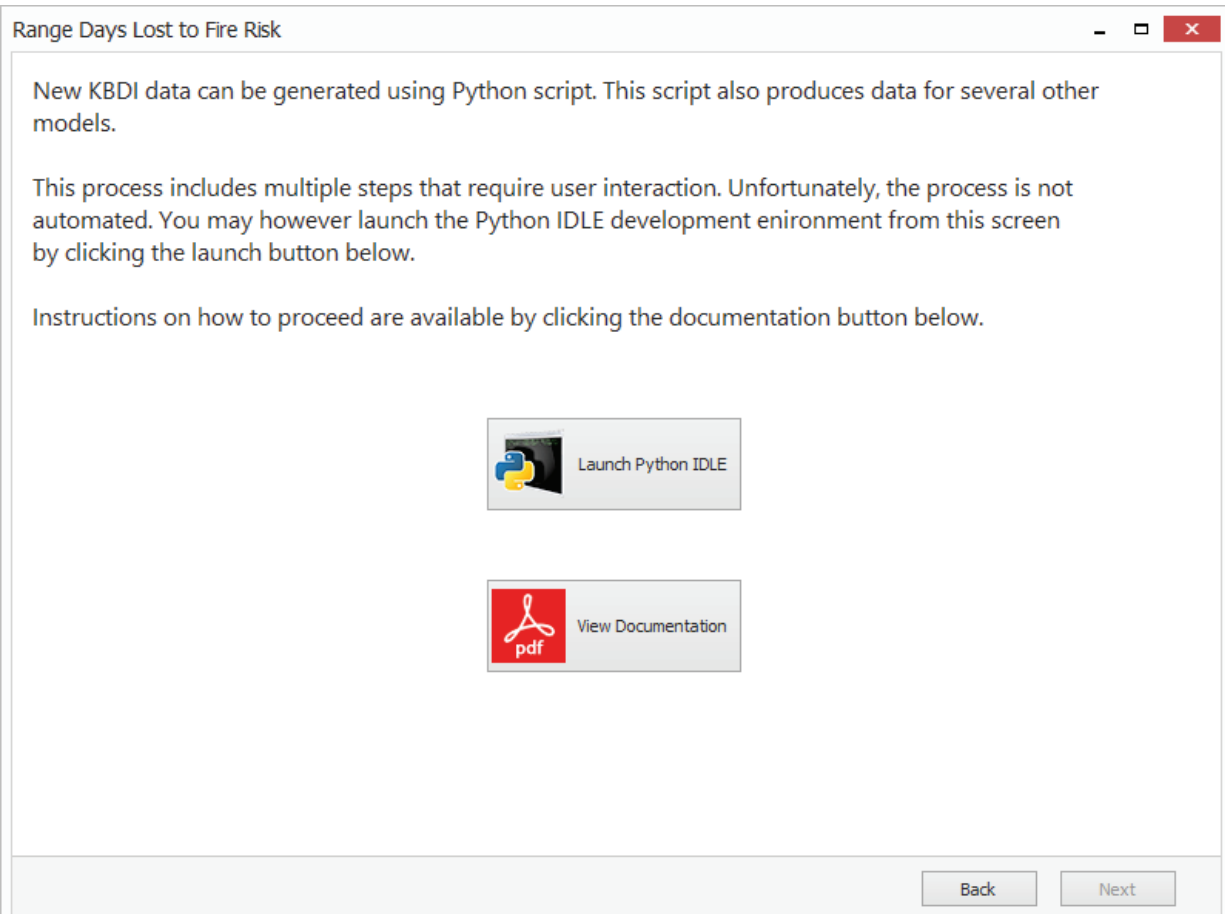


Figure 7. Python IDLE development environment.

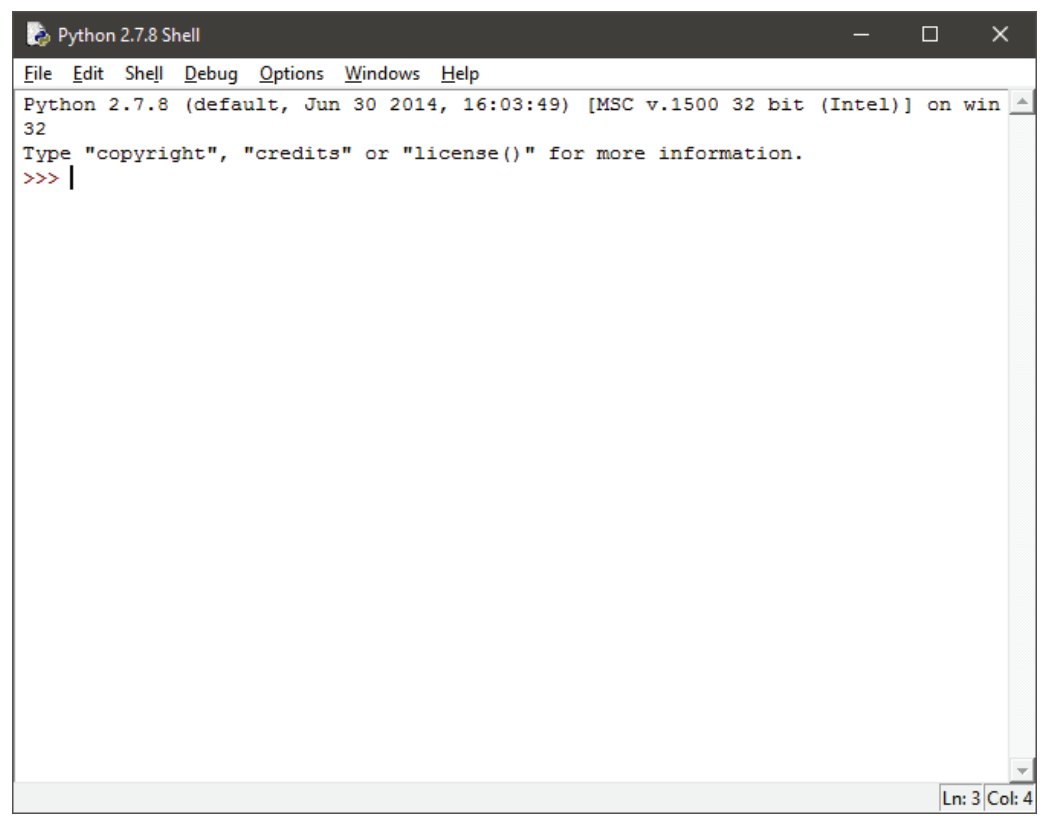

After opening IDLE, open the Python script by selecting File->Open and browse to the file $\mathrm{C}: \backslash$ Model $\backslash$ Shared-Data $\backslash$ Model $\backslash$ heat-fire risk days climate projections.py. Once the file is loaded, please ensure line 19 points to a text file that contains a list of GCMs to process. This file has been pre-made, so no adjustments to it should be necessary, unless new GCMs are to be processed. The file location is $C: \backslash$ Models $\backslash$ Data-2 $\backslash G C M$ Model Runs.txt. Use a text editor such as Microsoft Notepad to make modifications to this file. Also note that daily climate data from the Temperature and Precipitation Model must be processed prior to running this Fire Risk on Ranges Model. Refer to lines 16-18 for the file paths. If new climate data is to be processed, the files that are output from the Temperature and Precipitation Model must be located in the same prior directory, or lines 16-18 must be modified to match the location of the output files. Refer to the user's guide for that model for more information about its output files.

Output from this model is in the form of Comma Separated Values (CSV) files, one for each GCM/RCP combination. Please note that this process can be rather lengthy, depending on the number of GCMs that are being processed. It is not unusual for the script to run for several hours.

After running the Python script, another post processing script must be run. Locate the EXE file in the model folder within virtual machine. (C: \Models \Shared-Data \DataFixer.exe). Set the input and 
output paths by clicking the Change buttons. Ensure that the output folder that's entered exists before starting the process. Finally, click Fix It to process the data (Figure 8).

Figure 8. Data Fixer tool.

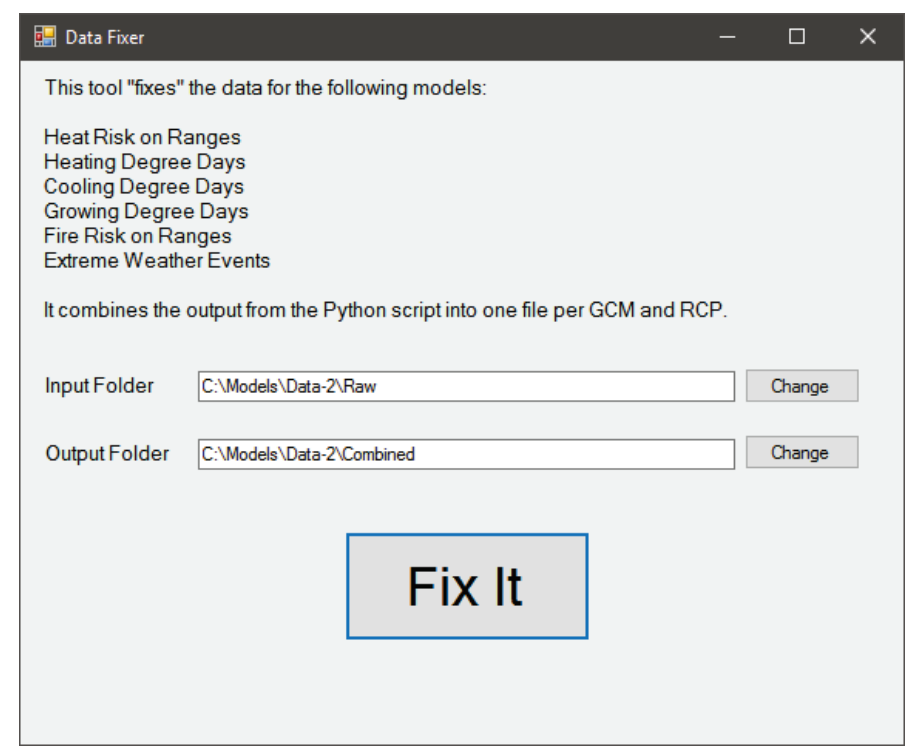

Post processing the data is fairly quick. It should not take more than a couple of minutes to complete. After this step, the data is ready to be viewed within the Wizard application. The post processing app source code is located at $\mathrm{C}: \backslash$ Models $\backslash \mathrm{VS}$ Projects $\backslash$ DataFixerHeatFire. 


\section{Known Issues and Limitations}

The KBDI is a measure of meteorological drought and reflects water gain or loss within the soil (USFS-WFAS 2017). It does not measure fuel moisture levels in the 1-10-hour fuel classes, which must be measured by other means for an accurate assessment of fuel moisture regardless of the drought index readings.

Building new data with this model can be a very lengthy process. Depending on the number of GCMs being processed, it's not unusual for the Python script to take several hours complete, even on very powerful, modern computers. 


\section{Additional Help}

Additional questions or concerns should be directed to the Program Manager of the Integrated Climate Assessment for Army Enterprise Planning program.

Paul M. Loechl

ERDC-CERL

Paul.M.Loech|@usace.army.mil

217-373-5892

Marty Garton

ERDC-ITL

Byron.m.garton@usace.army.mil

601-634-2888 


\section{References}

Garton, B. M. 2019. Analytical Model Software Integration Methods. ERDC/ITL SR-194. Vicksburg, MS: Information Technology Laboratory (ITL), U.S. Engineer Research and Development Center.

U.S. Forestry Service, Wildland Fire Assessment System (USFS-WFAS). 2017 Keetch and Byram Drought Index. https://www.wfas.net/index.php/keetch-byram-index-moisture-drought-49. Accessed 22 November 2017. 


\title{
Appendix A: Acronyms and Abbreviations
}

\author{
Term \\ Definition \\ CSV \\ Comma Separated Values \\ DoD \\ Department of Defense \\ ERDC \\ Engineer Research and Development Center \\ ERDC-CERL Engineer Research and Development Center- \\ Construction Engineering Research Laboratory \\ ERDC-ITL Engineer Research and Development Center- \\ Information Technology Laboratory \\ GCM \\ Global Circulation Model \\ JPEG \\ Joint Photographic Experts Group \\ KBDI \\ Keetch-Byram Drought Index \\ MVA \\ Military Value Analysis \\ NSN \\ National Supply Number \\ OMB \\ Office of Management and Budget \\ PM \\ Program Manager \\ RCP \\ Representative Concentration Pathway \\ SAR \\ Same As Report \\ USFS \\ U.S. Forest Service \\ $\mathrm{VM}$ \\ Virtual Machine \\ WFAS \\ Wildland Fire Assessment System
}




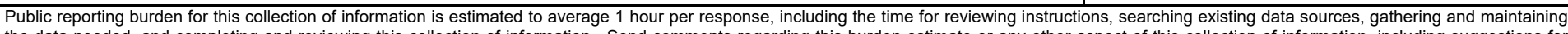

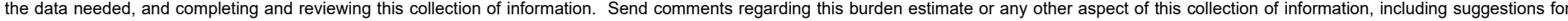

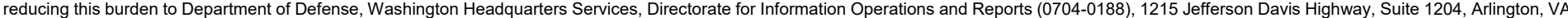

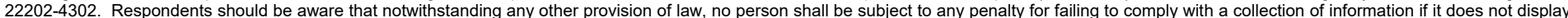
a currently valid OMB control number. PLEASE DO NOT RETURN YOUR FORM TO THE ABOVE ADDRESS.
1. REPORT DATE (DD-MM-YYYY) July 2019

4. TITLE AND SUBTITLE

Range Days Lost to Fire Risk Model User's Guide
3. DATES COVERED (From - To)

5a. CONTRACT NUMBER

5b. GRANT NUMBER

5c. PROGRAM ELEMENT NUMBER

5d. PROJECT NUMBER

402188

Byron M. Garton

5e. TASK NUMBER

5f. WORK UNIT NUMBER

8. PERFORMING ORGANIZATION REPORT NUMBER

ERDC/ITL SR-19-7

Information Technology Laboratory

U.S. Army Engineer Research and Development Center

3909 Halls Ferry Road

Vicksburg, MS 39180

9. SPONSORING / MONITORING AGENCY NAME(S) AND ADDRESS(ES)

10. SPONSOR/MONITOR'S ACRONYM(S)

Headquarters, U.S. Army Corps of Engineers

Washington, DC 20314-1000

11. SPONSOR/MONITOR'S REPORT NUMBER(S)

\section{DISTRIBUTION / AVAILABILITY STATEMENT}

Approved for public release; distribution is unlimited.

\section{SUPPLEMENTARY NOTES}

\section{ABSTRACT}

Maintaining and increasing the capacity to perform live fire training exercises on Department of Defense (DoD) lands is essential to future force readiness and effectiveness. The risk of fire on ranges as a potential result of climate change is one factor affecting the availability of training areas. Assessing the impact of future climate change is an essential part of ensuring future availability of live fire ranges.

This document describes the process of executing the Range Days Lost to Fire Risk Model, as it exists at the time of this writing, within the common computational environment established under the software integration effort of the Integrated Climate Assessment for Army Enterprise Planning work package.

\section{SUBJECT TERMS}

\section{Military bases}

Bombing and gunnery ranges

Rifle-ranges
Fire risk assessment

Climatic changes--Risk assessment

\section{SECURITY CLASSIFICATION OF:}

\section{a. REPORT}

Unclassified

b. ABSTRACT
Unclassified

\section{c. THIS PAGE}

Unclassified

\begin{tabular}{c|c}
$\begin{array}{c}\text { 17. LIMITATION } \\
\text { OF ABSTRACT }\end{array}$ & $\begin{array}{c}\text { 18. NUMBER } \\
\text { OF PAGES }\end{array}$ \\
SAR & 22 \\
\hline
\end{tabular}

19a. NAME OF RESPONSIBLE PERSON

19b. TELEPHONE NUMBER (include area code) 